\title{
The Response of Eggplant (Solanum Melongena L.) Growth Planted on Raised-Bog Peatland towards the Provision of Chicken Dung and Swallow Guano
}

\author{
Hariyadi $^{1 *}$ \\ ${ }^{1}$ Mathematics and Science Faculty, Indonesian Open University \\ Palangka Raya, Indonesia \\ e-mail : hariyadi@ecampus.ut.ac.id*
}

Received: September 25, 2020. Revised: November 25, 2020. Accepted: December 2, 2020.

Published: December 3, 2020.

\begin{abstract}
Eggplant (Solanum Melongena L.) is one of the agricultural commodities needed and a kind of vegetables favored because it is not only good in the taste, it also contains potassium and vitamin A which can be beneficial for the body. Eggplant production in Indonesia is low, but the need is high. So it is necessary to increase production, one of them is conducting agricultural extensification. Agricultural extensification can be carried out on land that has not been used properly, such as raised-bog peatland. On the other hand, raised-bog peatland is marginal land that is poor in nutrients and acidic in nature, so that the condition of the peatland is not supportive for plant growth. Therefore, it is necessary to add organic materials such as chicken dung and swallow guano to support the growth and yield of eggplant on raised-bog peatland. The purpose of this study was to determine the effect of chicken dung and swallow guano and their interaction on the yield of eggplant (Solanum Melongena L.) in the raised-bog peatland. This research used a group-randomized design (GRD) with 2 factors: chicken dung and swallow guano as fertilizer with 3 equal levels $(\mathrm{a} 1 / \mathrm{w} 1=5$ tons/ha; $\mathrm{a} 2 / \mathrm{w} 2=10$ tons/ha; a3/w3 $=15$ tons/ha). The parameter observed and measured were the yield of eggplant. The results showed that the single use of swallow guano as fertilizer had a significant effect on fruit diameter and length, the quantity of fruit for each plant, the average weight of fresh fruit, fruit weight for each plant, and fruit weight for each hectare. On the other hand, the use of chicken dung as fertilizer had a significant effect on the number of fruit per plant, fruit weight per plant, and fruit weight per hectare. The results showed that the best eggplant yield component was obtained from the addition of swallow guano fertilizer at a dose of $15 \mathrm{t}$ ha-1, namely resulted in a fruit weight per plant of 541,14 $\mathrm{g}$ tan-1 and a total fruit weight per ha of 12,88 $t$ ha-1. Whereas in chicken dung fertilizer treatment, the most optimum dose is $10 \mathrm{t}$ ha1 which can produce eggplant fruit weight per plant of $531,56 \mathrm{~g}$ tan-1 and 12,66 $\mathrm{t}$ ha-1 in total eggplant fruit weight per ha.
\end{abstract}

Keywords - chicken manure, swallow guano, outback peatland, Sweet Corn (Zea mays L. saccharata Sturt.)

\section{INTRODUCTION}

Eggplant (Solanum Melongena L.) is one of the most popular vegetable commodities in Indonesia, because besides it tastes good it also contains potassium and vitamin A which are beneficial to the body. However, the productivity produced by this eggplant crop is still low. Eggplant productivity in Indonesia is still at a number of low. This could happen because the price of eggplant is relatively low, so that many entrepreneurs in agriculture, including farmers, are reluctant to plant these crops. They prefer to cultivate their agricultural land to plant crops that have a higher economic value such as chilies, tomatoes, onions and mustard greens. Therefore, it is necessary to make efforts to increase eggplant production, one of them is conducting agricultural extensification.

Agricultural extensification is an effort to expand land to land that has not been used as agricultural land, so that land productivity increases [1],[2]. One of the agricultural extensification activities is to utilize marginal land such as the raised-bog peatland. Peat swamp marginal land is one of the lands that is acidic and lacks nutrients, so the plants cultivated on this land cannot grow properly and produce less optimum productivity. [3] states that the condition of peatlands does not support the rate and ease of providing sufficient nutrients for plants, especially for the availability of Potassium (K), Magnesium (Mg), and Calcium (Ca). Therefore, to be able to overcome these problems, it is necessary to add organic material in order to meet the nutritional needs of plants. Soil organic matter is the material used to improve the physical, chemical and biological structure of the soil, so that it can support plant growth and development properly. Organic fertilizers in the form of solid or liquid fertilizers which are used to improve the physical, chemical and biological properties of the soil. Organic fertilizers contain more organic matter than the nutritional level [4]-[7]. The use of organic fertilizers has a 
great influence on the physical, chemical, and biological properties of the soil. Therefore, the provision of organic fertilizers is considered very supportive on the efforts to increase the productivity of agricultural crops [8]-[10].

On the other hand, it is known that chicken dung is one of the organic fertilizers that has a higher $\mathrm{P}$ content than other livestock manure. The level of this nutrient depends on the food provided. In addition, chicken dung is a mixture of leftover chicken food and husks used as the base for the chicken coop. In several studies, chicken dung gives better results at the first time of planting because chicken dung is easy to rot and has sufficient nutrition when compared to other manure [11]. Meanwhile, swallow guano fertilizer (packaging fertilizer brand) is a product made from a mixture of guano, rock phosphate, zeolite, dolomite, and natural nutrients which are very useful for flowering, fertilizing plants and soil structure improvement [12]. Swallow Guano fertilizer is a type of fertilizer that dissolves slowly (slowly releasing), so it is more effective and efficient in use. Based on research, guano is an effective fertilizer because it has a high phosphorus and nitrogen content and has less odor. The composition of swallow guano organic fertilizer is: phosphate (P2O5) $14 \%$, phosphate (P2O5) dissolved in citric acid 10\%, nitrogen (N2) $1-2 \%$, potassium (K) $1 \%$, organic substances up to $24 \%$, max $5 \%$ water content, microelements of $\mathrm{Mg}, \mathrm{Al}, \mathrm{Fe}$, and others.

The purpose of this study was to determine the effect of chicken dung and swallow guano fertilizer and their interaction on the yield of eggplant (Solanum Melongena L.) in raised-bog peatland.

\section{MATERIAL AND METHOD}

The research was conducted on the raised-bog peatland owned by farmers located on Parawei Street, Menteng Village, Jekan Raya Subdistrict, Palangka Raya City, Central Kalimantan Province. The research was started in June - November 2018 using a randomized block design consisting of 2 factors, namely chicken manure/dung ( $\mathrm{a} 1=5 \mathrm{tha}^{-1} ; \mathrm{a} 2=10 \mathrm{t} \mathrm{ha}^{-1}$; $\mathrm{a} 3$ $\left.=15 \mathrm{tha}^{-1}\right)$ and swallow guano fertilizer ( $\mathrm{w} 1=5 \mathrm{t} \mathrm{ha}^{-1}$; $\mathrm{w} 2=$ $10 \mathrm{t} \mathrm{ha}^{-1}$; w3 $\left.=15 \mathrm{tha}^{-1}\right)$. The parameters observed and measured were the growth and yield of eggplant (Solanummelongena $\mathrm{L}$ ). There were 9 treatment combinations where each treatment consisted of 3 replications, so that 27 experimental units were obtained. Each experimental unit contains 20 plants with 6 sample plants. These results were analyzed using the $\mathrm{F}$ test, if the effect was significant or very significant, then continued with the comparison test of the mean treatment using Duncan's Multiple Range Test (DMRT) at a significant level of 0,05 .

\section{RESULTS AND DISCUSSION}

\section{Result}

Flowering Time : The flowering time of eggplant was observed when the sample plants flowered for the first time. The research results showed that there was no significant interaction or effect of each single factor of swallow guano fertilizer and chicken dung on the appearance time of eggplant flower for the first time. However, in this study, it was found that the time for the first eggplant flowers to appear namely on 34 - 36 days after planting.

Fruit Diameter and Length of Fruit: Observation of the diameter and length of eggplant fruit is carried out at the time of harvesting, namely at the age of 70 - 80 days after planting with the characteristics of the fruit elongated (oval), the flesh is not hard, the color of the fruit skin is bright and shiny, the fruit is not brownish and looks fresh. From the result of the analysis of variance shows that there is no interaction between the treatment of chicken dung and swallow guano fertilizer. But separately, only eggplant plants that were fertilized using swallow guano fertilizer which had a significant effect on the fruit diameter and fruit length of the eggplant. The average fruit diameter and fruit length of eggplant due to the effect of fertilization treatment using swallow guano fertilizer are presented in Table 1.

Based on Table 1, it is known that the diameter of eggplant fruit treated with swallow guano fertilizer at a dose of $15 \mathrm{t}$ ha-1 produces a fruit diameter that is larger than the dose of 5 t ha- 1 . Whereas on the length parameter of eggplant fruit also shows that swallow guano fertilizer with a dose of 15 tha-1 produces a longer fruit length compared to the doses of $5 \mathrm{t}$ ha- 1 and $10 \mathrm{t}$ ha-1.

Number of Fruits per Plant: Results of analysis of variance showed that there was no interaction between chicken dung and swallow guano fertilizer. However, separately, each treatment had a significant effect on the number of fruits per plant. The average number of fruits per plant due to the effect of the addition of chicken dung and swallow guano fertilizer is presented in Table 2 and Table 3.

Based on Table 2, it is known that the average number of fruits per plant is mostly produced by the addition of swallow guano fertilizer with the highest dosage namely amounted to $15 \mathrm{t}$ ha- 1 . While the dose of $5 \mathrm{t}$ ha-1 did not have a significant effect on the number of eggplant fruit per plant when compared to the addition of a dose of wallet guano fertilizer of $10 \mathrm{t}$ ha-1 and the two doses of fertilizer also produced a smaller number of fruit compared to the addition of a dose of swallow guano fertilizer amounted to $15 \mathrm{t}$ ha- 1 .

Based on Table 3, it is known that the addition of fertilizer doses of $10 t$ ha-1 and $15 \mathrm{t}$ ha- 1 can increase the number of fruits per plant more than the addition of fertilizer doses of $5 \mathrm{t}$ ha-1. From the table it is also known that an increase in doses of chicken dung of $10 \mathrm{t}$ ha- 1 provides the results of the number of eggplant per plant were not significantly different with the addition of chicken dung dose of 15 tha-1

Fresh Fruit Weight: The results of the analysis of variance on 
the observation of the average fresh fruit weight showed that there was no interaction between the treatment factors of chicken manure/dung and swallow guano fertilizer. However, separately, the single factor of swallow guano had a significant effect on the average fruit weight of eggplant per plant. Meanwhile, the addition of various doses of chicken manure/dung did not significantly influence the average fresh fruit weight per plant. The average effect of the single-factor of swallow guano fertilizer on the average fruit weight of eggplant plants is presented in Table 4.

Based on Table 4, it is known that the addition of fertilizer doses of $10 \mathrm{t}$ ha- 1 and $15 \mathrm{t}$ ha- 1 can increase fruit fresh weight per plant more than the addition of fertilizer doses of $5 \mathrm{t}$ ha- 1 . From the table it is also known that the addition of the dose of chicken dung of $10 \mathrm{t}$ ha-1 gives an average yield of eggplant fruit weight per plant which is not significantly different from the addition of the dose of chicken dung of $15 \mathrm{t}$ ha- 1 .

Fruit Weight per Plant and Fruit Weight per Hectare : The results of the analysis of variance showed that there was no interaction between the treatment of types of fertilizer and manure dose. However, separately, the single factor of swallow guano fertilizer and chicken dung had a significant effect on fruit weight per plant and per ha, respectively. The effect of the average fruit weight per plant and per ha due to the addition of chicken dung and swallow guano fertilizer at various doses is presented in Table 5 and Table 6 .

Based on Table 5, it is known that swallow guano fertilizer at a dose of $15 \mathrm{t}$ ha-1 gives the highest yield of fruit weight per plant and per ha compared to other treatments. While the lowest fruit weight per plant and per ha was obtained from the addition of fertilizer at a dose of $5 \mathrm{t}$ ha- 1 .

Based on Table 6, it is known that chicken dung at a dose of $10 \mathrm{t}$ ha-1 gave the yield of fruit weight per plant and per ha which was not significantly different from the dose of $15 \mathrm{t}$ ha1 , but the two treatments produced the highest fruit weight per plant and per ha compared with the treatment of the dose of chicken dung 5 tha-1

\section{Discussion}

Yield components are parameters that directly affect eggplant yields. The yield parameters in this study were the time of appearance of the first flower, fruit diameter, fruit length, number of fruits per plant, fresh fruit weight per plant, fresh fruit weight per ha. In the results of this study, there was no interaction between the type of fertilizer and the dose of fertilizer in all observation parameters. However, in the observation parameters when the first flower appeared, besides there was no interaction between the two treatment factors, there was also no significant effect on each treatment. This could happen because the treatment factor does not have a strong influence on eggplant plants, so that genetic factors have more influence on the appearance of flowers on eggplant. As explained by [13]-[21] that the determinants of plant growth can be external factors (nutrition and environment), and can also be internal factors (genetics and hormones).

The research results also showed that the application of Swallow Guano fertilizer and chicken dung separately had a significant effect on the observation parameters, namely the higher the dose given from the swallow guano fertilizer and chicken dung, the higher the yield components produced. Thus it can be said that the single effect of swallow guano fertilizer and chicken dung shows consistency in the development of crop yields. Swallow guano fertilizer and chicken dung are examples of organic ingredients. The provision of organic matter can increase plant growth, this is because the mineralization of organic matter releases macro and micro nutrients so that the availability of nutrients in the soil increases. The increase in nutrient availability will affect the increase in nutrient uptake so that the growth process increases [22]. A better growth process in the vegetative phase can determine the generative development of plants. So that with the development of plant vegetative organs will result in greater crop production.

In the observation parameters of fruit weight per plant and per ha, it was known that each type of fertilizer, namely swallow guano and chicken dung, gave results that had a significant effect on each fertilizer dose. Overall, the increase in the dosage on each type of fertilizer that was given resulted in an increase in fruit weight per plant and per ha. However, if further analyzed, it was found that the optimum dose that should be given to increase fruit weight per plant and per ha in swallow guano fertilizer is $15 \mathrm{t}$ ha- 1 , while in chicken dung is $10 \mathrm{t}$ ha-1. This is because, with a dose of chicken manure of $10 \mathrm{t}$ ha-1 alone can give results that are not significantly different from the dose of $15 \mathrm{t}$ ha-1. Meanwhile, to produce maximum fruit weight per plant and per ha in swallow guano fertilizer, a dose of $15 \mathrm{t}$ ha-1 should be used, because a dose of $10 \mathrm{t}$ ha- 1 has not been able to provide the same results as a dose of $15 \mathrm{t}$ ha-1 as in the type of the use of chicken dung.

According to [23]-[30], fertilizer is a major environmental factor that affects the yield potential of eggplant because the plant will grow and produce well depending on the fertilizer given to the plant. Plants cannot produce well without fertilization treatment that in accordance with plant needs. This is in line with [31] who explain that the yield formation phase requires high production rates and assimilation allocation on the seeds. The photosynthetic rate for assimilation production is influenced by the availability of nutrients. [32] added that the increase in yield and crop yield components was more influenced by the availability of $\mathrm{P}$ and K nutrients.

Phosphorus as ortho-phosphate has an important role in enzyme reactions that depend on phosphorylase. This is 
because all plant cell nucleus contains phosphorus which is essential in cell division and also for the development of meristem tissue [32]. [33] added that the $\mathrm{P}$ element functions more for root growth, especially to accelerate flowering and fruit ripening and increase fruit production. According to [34] guano has a higher phosphate content, so it is a source of organic [35] added that the provision of 20-25t ha-1 guano fertilizer was able to increase $\mathrm{P} 2 \mathrm{O}$ by $6,60-23,58 \mathrm{ppm}$ which is classified as high criteria. In addition to guano, chicken dung can also increase the availability of $P$ elements for plants as stated in [36], which states that chicken dung can increase soil fertility and productivity because the cation exchange capacity increases so that phosphorus and nitrogen elements also increase.

K Element functions to form protein and fat, the formation of carbohydrates, also strengthens fruit so that it does not break easily [33]. K element also functions as an enzyme activator in photosynthesis and respiration [37]. In addition, [38] also states that potassium plays a role in protein synthesis, carbohydrate metabolism which plays a role in starch formation, breakdown and translocation of starch and improves seed quality. [39] added that $\mathrm{K}$ elements play an important role in plant metabolism, including being directly involved in several physiological processes. The involvement of $\mathrm{K}$ elements in physiological processes is grouped into two, namely the biophysical aspect and the biochemical aspect. Viewed from the biophysical aspect of potassium, enzyme activity in the synthesis of carbohydrates and proteins increases the translocation of leaf photosynthesis. [40] stated that guano has $\mathrm{K}$ nutrient content ranging from 1,5 to $2 \%$ [8] explains that chicken dung contains $\mathrm{K}$ nutrients ranging from 0,4 to $2,9 \%$. Although it has a higher maximum reach, chicken dung also has a lower minimum reach compared to guano. So that the availability of the $\mathrm{K}$ element in guano is relatively more stable than in chicken dung. This is thought to result in a significant guano effect having a higher number of component parameters and yields than chicken dung. If detailed more specifically, it is known that swallow guano fertilizer has a significant effect with DMRT advanced test 5\% on parameters of fruit diameter, fruit length, number of fruits per plant, fruit weight per fruit, fruit weight per plant and fruit weight per ha, while chicken dung only had a significant effect on the differences in fertilizer doses on the observation parameters of the number of fruits per plant, fruit weight per plant and fruit weight per ha.

\section{CONCLUSION}

The best eggplant yield component was obtained from the addition of swallow guano fertilizer at a dose of $15 \mathrm{t}$ ha-1, which resulted in a fruit weight per plant of $541,14 \mathrm{~g}$ tan- 1 and a total fruit weight per ha of $12,88 \mathrm{t}$ ha-1. Whereas in chicken dung treatment, the most optimum dose is $10 \mathrm{t}$ ha- 1 which can produce eggplant fruit weight per plant of 531,56 g tan-1 and 12,66 t ha-1 in total eggplant fruit weight per ha.

\section{RECOMMENDATIONS}

For further research, it is advisable to conduct other studies on other soil types with more fertilization intervals or more diverse. Chicken dung and swallow guano can be used as an alternative fertilizer or repairer for the growth and yield of eggplant (Solanum Melongena L.), so that it is no longer a threat to environmental pollution.

\section{References}

[1] H. J. van Grinsven, J. W. Erisman, W. de Vries, H. Westhoek, and L. Lassaletta, "Potential of extensification of European and Dutch agriculture for a more sustainable food system focusing on nitrogen and livestock," in Just Enough Nitrogen, Springer, 2020, pp. 83-98.

[2] G. Fischer, A. Darkwah, J. Kamoto, J. Kampanje-Phiri, P. Grabowski, and I. Djenontin, "Sustainable agricultural intensification and gender-biased land tenure systems: an exploration and conceptualization of interactions," International Journal of Agricultural Sustainability, pp. $1-20,2020$.

[3] G. Soepardi, "Mengubah lahan liar menjadi kawasan usaha petani transmigrasi," Journal Penelitian dan Pengembangan Transmigrasi, vol. 3, pp. 19-23, 1986.

[4] R. Sutanto, "Penerapan Pertanian Organik Yogyakarta: Kanisius," 2002.

[5] J. Beeby, S. Moore, L. Taylor, and S. Nderitu, "Effects of a One-Time Organic Fertilizer Application on LongTerm Crop and Residue Yields, and Soil Quality Measurements Using Biointensive Agriculture," Frontiers in Sustainable Food Systems, vol. 4, p. 67, 2020.

[6] M. Tsioubri, D. Gasparatos, and M. EconomouEliopoulos, "Selenium Uptake by Lettuce (Lactuca sativa L.) and Berseem (Trifolium alexandrinum L.) as Affected by the Application of Sodium Selenate, Soil Acidity and Organic Matter Content," Plants, vol. 9, no. 5, p. 605, 2020.

[7] R. Noor, Z. Wang, M. Umair, M. Ameen, M. Misaal, and Y. Sun, "Long-term application effects of organic and chemical fertilizers on soil health and productivity of taramira (eruca sativa 1.) Under rainfed conditions," $J$ Anim Plant Sci, vol. 30, no. 4, pp. 970-987, 2020.

[8] E. I. Musnamar, "Pupuk organik: cair dan padat, pembuatan, aplikasi," Penebar Swadaya. Jakarta, vol. 72, 2003.

[9] D. Vyas, C. D. Nelson, J. J. Bromfield, P. Liyanamana, M. Krause, and G. E. Dahl, "MILK Symposium review: Identifying constraints, opportunities, and best practices for improving milk production in market-oriented dairy farms in Sri Lanka," Journal of Dairy Science, vol. 103, no. 11, pp. 9774-9790, 2020.

[10] A. Yassi, R. Amin, and N. Waldani, "Growth and production of three chili varieties with liquid organic fertilizer application,” 2020, vol. 575, no. 1, p. 012146. 
[11] W. Hartatik and L. Widowati, "Pupuk organik," Jurnal Pupuk Organik, 2008.

[12] M. Lestari, "Pupuk majemuk organik guano walet," 2011.

[13] M. Qibtiyah, "Pengaruh Penggunaan Konsentrasi Pupuk Daun Gandasil D Dan Dosis Pupuk Guano Terhadap Pertumbuhan Dan Produksi Tanaman Cabai Merah (Capsicum Annum L.)," Saintis, vol. 7, no. 2, pp. 109$122,2015$.

[14] N. Assan, "Dam breed effect and other dam related nongenetic factors as determinants of growth traits in goats and sheep production," 2020.

[15] S. Stuerz et al., "Climatic determinants of lowland rice development," Journal of Agronomy and Crop Science, vol. 206, no. 4, pp. 466-477, 2020.

[16] A. Vysochyna, N. Stoyanets, G. Mentel, and T. Olejarz, "Environmental Determinants of a Country's Food Security in Short-Term and Long-Term Perspectives," Sustainability, vol. 12, no. 10, p. 4090, 2020.

[17] L. Zhang, L. Yang, and W. Shen, "Dramatic altitudinal variations in leaf mass per area of two plant growth forms at extreme heights," Ecological Indicators, vol. 110, p. 105890, 2020.

[18] I. Arif, M. Batool, and P. M. Schenk, "Plant Microbiome Engineering: Expected Benefits for Improved Crop Growth and Resilience," Trends in Biotechnology, 2020.

[19] A. Kumar, S. Singh, A. K. Gaurav, S. Srivastava, and J. P. Verma, "Plant Growth-Promoting Bacteria: Biological Tools for the Mitigation of Salinity Stress in Plants," Frontiers in Microbiology, vol. 11, 2020.

[20] I. Afzal, Z. K. Shinwari, S. Sikandar, and S. Shahzad, "Plant beneficial endophytic bacteria: Mechanisms, diversity, host range and genetic determinants," Microbiological research, vol. 221, pp. 36-49, 2019.

[21] Ž. Piligrimienè, A. Žukauskaitè, H. Korzilius, J. Banyte, and A. Dovaliené, "Internal and external determinants of consumer engagement in sustainable consumption," Sustainability, vol. 12, no. 4, p. 1349, 2020.

[22] E. D. N. Hayanti and H. F. Yuliani, "Penggunaan kompos kotoran kelelawar (guano) untuk meningkatkan pertumbuhan tanaman kacang tanah (Arachis hypogaea)," LenteraBio, vol. 3, no. 1, pp. 7-11, 2014.

[23] P. Ai et al., "Effect of application of different biogas fertilizer on eggplant production: Analysis of fertilizer value and risk assessment," Environmental Technology \& Innovation, vol. 19, p. 101019, 2020.

[24] I. López-Cantarero, J. M. Ruiz, J. Hernandez, and L. Romero, "Nitrogen metabolism and yield response to increases in nitrogen- phosphorus fertilization: Improvement in greenhouse cultivation of eggplant (Solanum melongena cv. bonica)," Journal of Agricultural and Food Chemistry, vol. 45, no. 11, pp. 4227-4231, 1997.

[25] E. Amiri, A. A. Gohari, and Y. Esmailian, "Effect of irrigation and nitrogen on yield, yield components and water use efficiency of eggplant," African Journal of Biotechnology, vol. 11, no. 13, pp. 3070-3079, 2012.

[26] Z. Demir, "Effects of microbial bio-fertilizers on soil physicochemical properties under different soil water regimes in greenhouse grown eggplant (Solanum
Melongena L.)," Communications in Soil Science and Plant Analysis, vol. 51, no. 14, pp. 1888-1903, 2020.

[27] M. D. Maghfoer, R. Soelistyono, and N. Herlina, "Growth and yield of eggplant (Solanum melongena L.) on various combinations of $\mathrm{N}$-source and number of main branch," AGRIVITA, Journal of Agricultural Science, vol. 36, no. 3, pp. 285-294, 2015.

[28] R. Leogrande, O. Lopedota, C. Vitti, D. Ventrella, and F. Montemurro, "Effects of irrigation volumes and organic fertilizers on eggplant grown in Mediterranean environment," Acta Agriculturae Scandinavica, Section B-Soil \& Plant Science, vol. 64, no. 6, pp. 518-528, 2014.

[29] H. R. Bozorgi, "Effects of foliar spraying with marine plant Ascophyllum nodosum extract and nano iron chelate fertilizer on fruit yield and several attributes of eggplant (Solanum melongena L.).," Journal of agricultural and biological science, vol. 7, no. 5, pp. 357-362, 2012.

[30] G. A. Dias, R. H. C. Rocha, J. L. Araújo, J. F. Lima, and W. A. Guedes, "Growth, yield, and postharvest quality in eggplant produced under different foliar fertilizer (Spirulina platensis) treatments," Semina: Ciências Agrárias, vol. 37, no. 6, pp. 3893-3902, 2016.

[31] H. E. Reinoso, C. N. Travaglia, and A. R. Bottini, $A B A$ increased soybean yield by enhancing production of carbohydrates and their allocation in seed. Intech Open Access Publisher, 2011.

[32] E. S. Sarief, "Kesuburan dan pemupukan tanah pertanian," Pustaka Buana. Bandung, vol. 182, 1986.

[33] I. Novizan, "Petunjuk Pemupukan yang Efektif," AgroMedia Pustaka, Jakarta, 2002.

[34] I. Isrun, "Respons Inceptisols Terhadap Pupuk Guano Dan Pupuk P Serta Pengaruhnya Terhadap Serapan P Tanaman Kacang Tanah,” Agroland: Jurnal Ilmu-ilmu Pertanian, vol. 16, no. 1.

[35] R. Syofiani and G. Oktabriana, "Aplikasi Pupuk Guano dalam Meningkatkan Unsur Hara N, P, K, dan Pertumbuhan Tanaman Kedelai pada Media Tanam Tailing Tambang Emas," Prosiding SEMNASTAN, pp. 98-103, 2018.

[36] O. Dikinya and N. Mufwanzala, "Chicken manureenhanced soil fertility and productivity: Effects of application rates," Journal of Soil Science and Environmental Management, vol. 1, no. 3, pp. 46-54, 2010.

[37] K. Hanafiah, "Dasar-dasar ilmu tanah: Jakarta," Raja Grafindo Persada, 2005.

[38] M. Sutedjo, "Pupuk dan Cara Pemupukan. Cetakan-9," PT. Rineka Cipta. Jakarta, 2010.

[39] N. K. Fageria, The use of nutrients in crop plants. CRC press, 2016.

[40] P. Lingga, Petunjuk penggunaan pupuk. Niaga Swadaya, 2001.

\section{Creative Commons Attribution License (Attribution 4.0 International, CM3 BY 4.0)}

This article is published under the terms of the Creative Commons Attribution License 4.0 https://creativecommons.org/licenses/by/4.0/deed.en US 
Table 1. The average effect of swallow guano on the diameter and length of eggplant fruit $(\mathrm{cm})$

\begin{tabular}{|l|ll|ll|}
\hline Swallow Guano & \multicolumn{3}{|l|}{ Diameter of Fruit $(\mathrm{cm})$} & \multicolumn{3}{l|}{ Length of Fruit $(\mathrm{cm})$} \\
\hline $\mathrm{w}_{1}\left(5 \mathrm{t} \mathrm{ha}^{-1}\right)$ & 4,15 & $\mathrm{a}$ & 27,94 & $\mathrm{~A}$ \\
$\mathrm{w}_{2}\left(10 \mathrm{tha}^{-1}\right)$ & 4,22 & $\mathrm{ab}$ & 29,37 & $\mathrm{~A}$ \\
$\mathrm{w}_{3}\left(15 \mathrm{t} \mathrm{ha}^{-1}\right)$ & 4,37 & $\mathrm{~b}$ & 32,14 & $\mathrm{~B}$ \\
\hline
\end{tabular}

Note: The numbers followed by the same letter show no significant difference according to the DMRT test at a significant level of $5 \%$

Table 2. The average effect of swallow guano on the quantity of fruit for each plant

\begin{tabular}{|l|ll|}
\hline Swallow Guano & Fruit Quantity for Each Plant \\
\hline $\mathrm{w}_{1}\left(5 \mathrm{t} \mathrm{ha}^{-1}\right)$ & 2,76 & $\mathrm{a}$ \\
$\mathrm{w}_{2}\left(10 \mathrm{t} \mathrm{ha}^{-1}\right)$ & 2,80 & $\mathrm{a}$ \\
$\mathrm{w}_{3}\left(15 \mathrm{t} \mathrm{ha}^{-1}\right)$ & 3,00 & $\mathrm{~b}$ \\
\hline
\end{tabular}

Note: The numbers followed by the same letter show no significant difference according to the DMRT test at a significant level of $5 \%$

Table 3. The average effect of chicken dung on the quantity of fruit for each plant

\begin{tabular}{|c|c|}
\hline Chicken Dung & Fruit Quantity for Each Plant \\
\hline$a_{1}\left(5 t_{h a}^{-1}\right)$ & 2,67 \\
\hline$a_{2}\left(10 t h^{-1}\right)$ & 2,98 \\
\hline$a_{3}\left(15 t_{h a}^{-1}\right)$ & 2,95 \\
\hline
\end{tabular}

Note: The numbers followed by the same letter show no significant difference according to the DMRT test at a significant level of $5 \%$

Table 4. The average effect of swallow guano on the average weight of fresh fruit (gr)

\begin{tabular}{|l|lc|}
\hline Swallow Guano & \multicolumn{3}{|l|}{ The Average Weight of Fresh Fruit (gr) } \\
\hline $\mathrm{w}_{1}\left(5 \mathrm{t} \mathrm{ha}^{-1}\right)$ & 167,03 & A \\
$\mathrm{w}_{2}\left(10 \mathrm{t} \mathrm{ha}^{-1}\right)$ & 176,32 & $\mathrm{~B}$ \\
$\mathrm{w}_{3}\left(15 \mathrm{t} \mathrm{ha}^{-1}\right)$ & 180,32 & $\mathrm{~B}$ \\
\hline
\end{tabular}

Note: The numbers followed by the same letter show no significant difference according to the DMRT test at a significant level of $5 \%$

Table 5. Average effect of swallow guano on fruit weight for each plant and fruit weight for each hectare

\begin{tabular}{|l|lc|ll|}
\hline Swallow Guano & \multicolumn{2}{|l|}{ Fruit Weight for each Plant(g) } & \multicolumn{2}{|l|}{$\begin{array}{l}\text { Fruit Weight for each Hectare } \\
\text { (ton) }\end{array}$} \\
\hline $\mathrm{w}_{1}\left(5 \mathrm{tha}^{-1}\right)$ & 461,10 & $\mathrm{a}$ & 10,98 & $\mathrm{a}$ \\
$\mathrm{w}_{2}\left(10 \mathrm{tha}^{-1}\right)$ & 500,10 & $\mathrm{~b}$ & 11,91 & $\mathrm{~b}$ \\
$\mathrm{w}_{3}\left(15 \mathrm{tha}^{-1}\right)$ & 541,14 & $\mathrm{c}$ & 12,88 & $\mathrm{c}$ \\
\hline
\end{tabular}

Note: The numbers followed by the same letter show no significant difference according to the DMRT test at a significant level of $5 \%$

Table 6. Average effect of chicken dung on fruit weight for each plant and fruit weight for each hectare

\begin{tabular}{|l|lc|lc|}
\hline Chicken Dung & \multicolumn{2}{|l|}{ Fruit Weight for each Plant(g) } & \multicolumn{2}{|l|}{$\begin{array}{l}\text { Fruit Weight for each Hectare } \\
\text { (ton) }\end{array}$} \\
\hline $\mathrm{a}_{1}\left(5 \mathrm{tha}^{-1}\right)$ & 459,48 & $\mathrm{a}$ & 10,94 & $\mathrm{~A}$ \\
$\mathrm{a}_{2}\left(10 \mathrm{t} \mathrm{ha}^{-1}\right)$ & 531,56 & $\mathrm{~b}$ & 12,66 & $\mathrm{~B}$ \\
$\mathrm{a}_{3}\left(15 \mathrm{tha}^{-1}\right)$ & 511,29 & $\mathrm{~b}$ & 12,17 & $\mathrm{~B}$ \\
\hline
\end{tabular}

Note: The numbers followed by the same letter show no significant difference according to the DMRT test at a significant level of $5 \%$ 